\title{
POLITIKK
}

SKANDINAVISK TIDSSKRIFT

FOR INTERNASIONALE STUDIER

Årgang 79, Nummer 4, side 411-437, 2021, ISSN 1891-1757, www.tidsskriftet-ip.no, Publisert desember 2021

\section{Ja eller nei til Huawei? En analyse av hvordan små og mellomstore stater stiller seg til den kinesiske gigantens rolle i $5 \mathrm{G}$}

\author{
Øystein S. Christie \\ Norges teknisk-naturvitenskapelige universitet - NTNU, Norge
}

\begin{abstract}
Sammendrag
Artikkelen ser på den teknologiske og strategiske rivaliseringen mellom USA og Kina hva gjelder implementeringen av 5G-nettverk, og spør hva som er med å påvirke hvordan andre stater posisjonerer seg mellom de to supermaktene. Ved å bygge på tre grener av politisk realisme - balance-of-threat-teoriens tanke om at trusseloppfatning driver staters valg av allianser, patron-klient-teoriens tro på at USA kan forvente at deres klientstater innretter seg etter amerikansk utenrikspolitikk, og teorien om at handelsrelasjoner kan brukes som maktverktøy - utleder jeg et sett med hypoteser og potensielt relevante forklaringsvariabler. Som avhengig variabel samler jeg 70 staters holdninger til Kinas omstridte telekommunikasjonsgigant Huaweis rolle i 5G. Bivariat analyse avslører tre hovedmønstre: (1) Stater som er små og maktesløse i forhold til Kina, samt statene i Kinas geografiske region, ser ut til å være mer aksepterende til Huaweis 5G. (2) Stater som ser på USA som sin patron og som er avhengige av Washingtons sikkerhetsgaranti ser ut til å være betydelig mer avvisende til selskapets 5G. (3) Handelsrelasjoner til både USA og Kina ser ut til å ha liten eller ingen effekt på staters holdninger. Av de tre realisme-grenene er det altså patron-klient-teorien som veier tyngst når det gjelder å forklare staters holdninger til Huaweis $5 \mathrm{G}$.
\end{abstract}

Nøkkelord: allianser • balansering • bandwagoning • USA-Kina-rivalisering • politisk realisme

\footnotetext{
^Kontaktinformasjon: Øystein S. Christie, e-post: oystein.christie@ntnu.no

(C2021 Øystein S. Christie. This is an Open Access article distributed under the terms of the Creative Commons Attribution 4.0 International License (https://creativecommons.org/licenses/BY/4.0/), allowing third parties to copy and redistribute the material in any medium or format and to remix, transform, and build upon the material for any purpose, even commercially, provided the original work is properly cited and states its license.

Citation: Christie, Ø. S. (2021). Fa eller nei til Huawei? En analyse av hvordan små og mellomstore stater stiller seg til den kinesiske gigantens rolle i 5G. Internasjonal Politikk, 79(4), 411-437. http://dx.doi.org/10.23865/intpol.v79.3284
} 


\section{Introduksjon}

Forholdet mellom de to mektigste landene i verden er på nedadgående kurve. I fire år fortsatte president Trump og hans administrasjon å yppe til bråk med nærmest alt de så for seg at kunne øke Kinas internasjonale innflytelse (f.eks. Wong \& Hautala, 2020). President Biden startet sin valgkampanje med å dysse ned amerikaneres frykt for at Kina var "out to eat our lunch", men også han har lagt seg på en mye strengere linje etter hvert (f.eks. Martina, 2020; Walt, 2020; Zengerle, 2021). Dette reiser spørsmålet om et større sammenstøt mellom USA og Kina nærmer seg.

USAs attraktivitet som strategisk partner er åpenbar; det er stadig det mektigste landet i verden, både økonomisk og militært. En rekke forskere understreker USAs fortsatte forrang og sentralitet i verdensbegivenhetene (f.eks. Beckley, 2018; Brands, 2016; Brooks \& Wohlforth, 2016; Gates, 2020; Huntington, 1999). Som følge av dette er det mange i Washington som ser på det som en selvfølge at de vil få bred støtte i ethvert diplomatisk, økonomisk eller militært oppgjør med Beijing.

Samtidig kan man ikke, og burde ikke, overse Kinas betydelige tiltrekningskraft som en alternativ strategisk partner. Freedom House sine årlige rapporter avslører at demokrati er i retrett over hele verden, en trend som har vokst i styrke i 15 år. I det ideologiske vakuumet etterlatt av vestlig-inspirert liberalt demokrati, har den kinesiske autoritære modellen klart å tilby et potent alternativ. I løpet av de siste tiårene har Kina sakte, men sikkert vokst til å bli en av de mest aktive og multilaterale spillerne på verdensarenaen (Christensen, 2015, kap. 1).

Dette har ført til spekulasjon om en vordende kinesisk orden blant ikke-vestlige stater i stor vekst, representert ved konseptet Beijing Consensus, som spår at Kinas økonomiske suksess kan tilby utviklingsland en alternativ modell til det rådende Washington Consensus (Fengming, 2005; Williamson, 2008). På langt nær alle forskere er enige $i$ at en slik endring er underveis (Kennedy, 2010), men flere hevder hardnakket at tiden der Kina var «bereft of friends» og «a beacon to no one» ser ut til å være over (Strüver, 2014, 2016).

Siden begge de mektigste landene i verden er attraktive på sine måter, er det trolig ikke lenger en selvfølge at USA vil få støtte fra store deler av verden i sin rivalisering med Kina. Redaktøren i The Atlantic, Uri Friedman (2020), skriver: «Despite the network of global alliances Washington has built up, it's been unable to convince those allies to hop on the 'great-power-competition express' and leave China behind.» Hun sier videre at hvis USA er fast bestemt på å gjenskape den kalde krigens todelte verden, der de utfordrer Kina på alle områder mens de forventer at sine støttespillere gjør det samme, «it will likely find itself largely isolated» (se også Solheim, 2020).

Så hvordan kan vi vite, eller i det minste få noen indikasjoner på, hvordan andre stater vil stille seg mellom de to? Og hva kan disse statenes posisjonering fortelle oss om framtidsutsiktene for alliansepolitikk? Dette er spørsmål denne artikkelen tar for seg. Mer spesifikt er mitt forskningsspørsmål følgende: Hvilke faktorer kan 
ha betydning for hvordan verdens små og mellomstore stater stiller seg til Kinas jakt etter innflytelse, når de samtidig pålegges press fra USA om å fryse ut Beijing?

Artikkelen tar for seg disse og beslektede spørsmål med teoretisk grunnlag i politisk realisme, der makt ses på som valutaen i internasjonal politikk. Jeg utelukker ikke at andre teoretiske retninger kan ha relevante bidrag til disse debattene, men jeg ser kun på realisme. Mer spesifikt vil strukturell realisme være kilde for mye av mitt resonnement, da jeg gir forrang til systemiske krefter. For slike realister er grunnprinsippet at «differential growth rates, which over time change the relative distribution of capabilities between states, are the driving forces of international politics» (Ripsman et al., 2016, s. 17). Følger vi denne logikken, og observerer at Kinas vekst er langt større enn USAs på en rekke samfunnsarenaer, bør vi alle feste setebeltene for turbulente tider fremover (se også Gilpin, 1981; Kennedy, 1987).

Som kilde for avhengig variabel, bruker artikkelen en dagsaktuell case; den kinesiske telekommunikasjonsgiganten Huawei og USAs globale presskampanje for å undertrykke dets rolle i implementering av $5 \mathrm{G}$ verden rundt. Jeg samler 70 staters holdninger til Huaweis $5 \mathrm{G}$ ved å plassere dem på en 6-punkts skala som går fra fullt ut aksepterende til fullt ut avvisende. Deretter utforsker jeg drivkreftene bak disse holdningene ved å korrelere dem med en rekke forklaringsvariabler fra tre grener av realismen. Hva bidrar til å dytte stater opp eller ned på denne skalaen? Er det graden av trussel som den aktuelle staten oppfatter fra Kina, dens avhengighet av USA som sikkerhetsgarantist, eller dens handelsrelasjoner til en av de to supermaktene? Eller en kombinasjon av disse?

En åpenbar svakhet ved denne tilnærmingen er temaets betydelige kompleksitet. Jeg kan umulig dekke alle tenkelige aspekter av det, og det er derfor uunngåelig at det er faktorer utenfor artikkelens rekkevidde som har innvirkning på staters holdninger til Huaweis 5G. I tillegg er 70 observasjoner forholdsvis lite for kvantitative metoder, og datasettet vil derfor være sårbart for spuriøse effekter. En tredje potensiell svakhet ligger i at jeg baserer meg på relativt gamle teoretiske verk. Noen analyser vil argumentere for at maktmekanismene og maktformene har endret seg i takt med den digitale tidsalder (f.eks. Ansorge, 2016), men mitt argument, som tar utgangspunkt i realismens logikk, er at parallelt med dette har grunnprinsippene for makt i all hovedsak holdt seg konstante.

Artikkelen tar også sikte på å bruke eksisterende forskning til å belyse sider av rivaliseringen mellom USA og Kina som i liten grad har blitt belyst tidligere. Siden årtusenskiftet, og spesielt i løpet av de siste årene, er det en lang liste av forskere og kommentatorer som har delt synspunkter om det nåværende og fremtidige forholdet mellom USA og Kina (f.eks. Allison, 2017; Christensen, 2015; Etzioni, 2017; Friedberg, 2011, 2018; Mahbubani, 2020; Wang, 2020). Fokuset i disse tekstene er dog nesten utelukkende på USA og Kina selv; så langt har mye mindre blitt sagt om små og mellomstore tredjepartstater og hvordan disse ville posisjonert seg i en større konflikt mellom supermaktene. 
På samme måte: Mens mye er skrevet om Huawei, dets bånd til det kinesiske kommunistpartiet (CCP), og USAs kritikk mot det (f.eks. Lindsay et al., 2015; Lysne, 2018; Wang, 2020), er det få analyser av sekundære staters valg rundt selskapet. En av disse er Waldemarsson og Löwenberg (2020), som analyserer Huaweidebatten i EU. Min artikkel tar opp mye av det samme, men sikter samtidig bredere, da jeg tar for meg flere stater også utenfor den europeiske union.

Et tredje nyere aspekt ved artikkelen handler om hvordan den stiller seg i faglitteraturen om allianser. Denne litteraturen har et enormt omfang (f.eks. Liska, 1962; Rothstein, 1968; Snyder, 1984; Walt, 1987), og en rekke forskere har argumentert for at den på ingen måte er enhetlig (Aggarwal \& Kapoor, 2018; Bueno de Mesquita \& Singer, 1973; Burgess \& Moore, 1972; Holsti et al., 1973). I Wards (1982, s. 5) gjennomgang av mer enn 270 artikler og bøker om alliansedynamikk, for eksempel, er hans hovedfunn at den samlede allianselitteraturen er svært divergent og ikke særlig kumulativ. I det følgende vil jeg bruke allianselitteraturen som grunnlag for å belyse dagens intensiverende rivalisering mellom USA og Kina.

Jeg strukturerer artikkelen på følgende måte: I neste del skal jeg kort presentere artikkelens empiriske kilde, casen om Huaweis rolle i 5G. Etter det følger en teoridel hvor jeg gjennomgår tre grener av politisk realisme, og bruker disse til å utlede artikkelens tre hypoteser. Deretter følger data og metode, som dekker utvalget av mitt panel av stater, samt hvordan jeg har operasjonalisert og målt variablene. Den påfølgende analysen er delt i tre bivariate modeller, en for hver hypotese. I hver av disse undersøker jeg korrelasjonen mellom den avhengige og de uavhengige variablene, med mål om å tilføre enten styrkende eller svekkende bevismateriale til hypotesene. Jeg avslutter artikkelen med en konklusjon, som inkluderer en oppsummering av funnene og en diskusjon rundt styrken i disse.

\section{Empirisk kilde}

USA har i lang tid ført en intensiv presskampanje mot den kinesiske telekommunikasjonsgiganten Huawei, der de aktivt har prøvd å begrense selskapets rolle i implementeringen av femtegenerasjons nettverk (5G) verden rundt. Det er mye bekymring i Washington for at Huawei i stor grad er et verktøy som det kinesiske kommunistpartiet (CCP) kan bruke til å spionere på selskapets brukere. Det er allment kjent at Huawei mottar betydelig finansiell støtte fra staten (f.eks. Grotto, 2019). Spørsmålet er hvorvidt dette legger selskapet under den aktive innflytelsen til CCP eller ikke. På sin side har Huawei konsekvent nektet for alle slike anklager som har blitt rettet mot dem, og har hele tiden holdt fast ved at det er et uavhengig selskap som ville kunnet si nei selv hvis de kinesiske myndighetene hadde bedt dem om å spionere eller lignende. Dette forandrer åpenbart ikke hva beslutningstakerne i Washington tenker; allerede i 2012 fordømte US House Intelligence Committee Huawei, og hevdet at de utgjorde en trussel mot nasjonal sikkerhet (Marek \& Dutta, 2019).

USAs restriksjoner mot Huawei eskalerte kraftig under Donald Trumps presidentperiode; selv før han ble president virket det som om han hadde pekt ut selskapet 
som en slags erkefiende. Han ga Huawei et spesielt hardt slag i mai 2019, da det hvite hus forbød enhver stat eller person vurdert som en "utenlandsk fiende» fra å selge telekommunikasjonsutstyr i USA. I praksis hindret dette Huawei fra å investere i implementeringen av USAs 5G nettverk. 14 mai 2020 utvidet Trump dette forbudet i ett år til (Keane, 2020).

Er det grunnlag for USAs bekymringer? På enkelte måter er svaret ja, om ikke annet fordi det er så mye som står på spill i disse spørsmålene. "Any bug, beacon, or backdoor put into our critical systems could allow for a catastrophic and devastating domino effect of failures throughout our networks» (Rogers \& Ruppersberger, 2012). Også hvis vi følger den harde logikken i politisk realisme, gir motstanden mening. Det er bred enighet om at den som kontrollerer verdens 5G-teknologi vil ha en enorm strategisk fordel i framtiden. I den grad Huawei virkelig er en av CCPs armer, vil det at Huawei får den strategiske fordelen av $5 \mathrm{G}$ i stor grad bety at Kina får denne strategiske fordelen. I realistenes nullsumsverden vil det innebære et stort tap i relativ makt for USA. Og Washington kan ikke la det skje.

I løpet av de siste årene har derfor USAs ledende politikere vært på verdensturne med en enkel beskjed: «It's the US way or the Huawei.» I februar 2019 tok Washington kampen til Europa, da de egget sine europeiske allierte til å holde seg unna Huaweis utstyr i sine 5G-nettverk (Collins, 2019). Kort tid etter uttalte USAs statssekretær Mike Pompeo at stater som brukte Huaweis utstyr utgjorde en betydelig risiko for USA; i de mest ekstreme tilfellene, advarte Pompeo, ville delt etterretning, diplomatiske bånd og militære partnerskap være utelukket. Dette var antagelig en dårlig fordekt trussel mot stater som forble positive til de kinesiske gigantene (Chrysoloras \& Bravo, 2019; Zhou, 2019). I august $2020 \mathrm{kom}$ det hittil mest tungtveiende tiltaket, da USA lanserte sitt «Clean Network»-program, som tok sikte på å motvirke «longterm threats to data privacy, security and human rights posed to the free world from authoritarian malign actors, such as the Chinese Communist Party» (Gramer, 2020).

Generelt har presskampanjen mot Huawei og dets rolle i implementeringen av 5G hatt en del suksess. Dette var særlig tilfelle i det siste året av Trumps presidentskap, da nye stater innførte kraftige restriksjoner mot selskapet nærmest hver måned. En håndfull stater har nå nedlagt fullt forbud mot Huawei i byggingen av $5 \mathrm{G}$, andre har signert såkalte 5G-sikkerhetsavtaler med USA, og andre igjen har gitt større 5G-kontrakter til Nokia og/eller Ericsson, Huaweis hovedkonkurrenter, eller til lokale aktører. Likevel er verden ganske langt unna det enstemmige forbudet mot Huawei som USA ser ut til å ønske seg; en minst like stor gruppe med stater bruker, eller planlegger å bruke, Huawei aktivt i sine 5G-nettverk, mens andre utviser generell motvilje mot å ekskludere Huawei fra $5 \mathrm{G}$. Hvilke faktorer kan ligge bak disse variasjonene?

\section{Teorier om alliansedannelse og -dynamikk}

Et mer fundamentalt aspekt ved forskningsspørsmålet gielder valg av side i den potensielt kommende konflikten: Hva kan staters posisjonering i rivaliseringen 
mellom USA og Kina fortelle oss om hvor de står med tanke på alliansepolitikk? En sentral del av den politiske realismen er troen på maktbalansemekanismen som et overordnet prinsipp i internasjonale relasjoner. Ifølge denne logikken vil stater alltid søke å hindre andre $\mathrm{i}$ å bli for mektige, siden det uunngålig vil få disse til å prøve å dominere andre. Prøver stater i dag å balansere mot enten Kina eller USA, eller bruker de andre strategier for å unngå å bli dominert eller til og med angrepet selv?

Helt siden lanseringen av begrepet the unipolar moment om USAs posisjon som verdens nummer én, ${ }^{1}$ har forskere satt spørsmålstegn ved om det kan vare. Christopher Layne, for eksempel, skrev om the unipolar illusion i 1993, og har tatt opp igjen temaet flere ganger siden (Layne, 2006, 2018). Med grunnlag i strukturell realisme argumenterte han for at the unipolar moment kun var en geopolitisk mellomstasjon som snart ville vike for multipolaritet, motbalansering og framvekst av nye stormakter. De som sa noe annet var rett og slett naive, fastholdt han: «Proponents of America's preponderance have missed a fundamental point $[\ldots]$ other states react to the threat of hegemony, not to the hegemon's identity. American leaders may regard the United States as a benevolent hegemon, but others cannot afford to take such a relaxed view» (Layne, 1993, s. 36). Ifølge ham er altså motbalansering av USA absolutt en mulighet - kanskje til og med noe vi burde forvente.

Det har samtidig vært mange forskere opp igjennom årene som har holdt fast ved at USA er en eksepsjonell hegemon som få frykter og nesten ingen noen gang vil ønske å balansere mot (Brooks \& Wohlforth, 2005, 2008; Levy \& Thompson, 2010; Lieber \& Alexander, 2005). For disse teoretikerne er motbalansering av Kina et mye mer håndgripelig alternativ. John Mearsheimer (f.eks. 2001, 2006, 2014) er trolig den mest prominente forskeren som foreslår dette. Han mener det er umulig for Kina å holde på en fredelig framvekst. For flere år siden predikerte han at USA og Kina snart ville bli fanget $i$ en intens rivalisering, der flesteparten av Kinas naboer, $i$ tillegg til mye av resten av verden, ville slå seg sammen med USA for å demme opp for Beijing (Mearsheimer, 2006, s. 160). Grunnen til dette, sa han, er enkel: Kina utgiør en mer seriøs trussel mot stater i Asia og stillehavsområdet enn hva USA giør. Og ifølge logikken $i$ hans egen teori, vil stater balansere mot det de ser som den mest seriøse trusselen (Mearsheimer, 2014, s. 24).

Er en eller begge disse mulighetene, eller i det minste elementer av dem, til stede i dag? Ettersom staters sanne intensjoner alltid må behandles som ukjente i internasjonal politikk, er dette høyst komplekse spørsmål, med tilsvarende komplekse svar. En tilleggsutfordring er usikkerheten i tidsaspektet; mens maktbalanseteorien er god til å predikere at motbalansering uunngåelig vil oppstå når for mye makt blir konsentrert $\mathrm{i}$ hendene til én stormakt, kan den ikke si nøyaktig når dette vil skje (f.eks. Waltz, 1979, s. 3). Altså kan ingen noen gang si med sikkerhet hva som

\footnotetext{
${ }^{1}$ Ideen om at den kalde krigens slutt etterlot USA som en ubestridt verdensleder (se Krathammer, 1990). For et lignende argument, se Fukuyamas begrep om «the end of history» (1989).
} 
virkelig foregår hva gjelder alliansepolitikk og balansering. Jeg kan dermed ikke forvente å finne faste svar på disse sekundære spørsmålene. Det jeg derimot gjør, er å ta et stillbilde av dagens situasjon og rette søkelyset mot disse temaene. Det å observere hvordan og hvorfor stater stiller seg som de gjør til Huaweis 5G, kan kanskje avsløre noe om trendlinjene i dagens balanseringslandskap.

\section{Walt: Trusseloppfatning fra Kina}

I sin teori om trusselbalanse bearbeider og modifiserer Stephen M. Walt (1987) den klassiske maktbalanseteorien. For Walt styres en stats alliansebeslutninger ikke bare av fordelingen av maktressurser, som er den konvensjonelle ideen, men heller av den bredere trusselen som staten oppfatter fra andre stater. Maktressurser er altså bare én av komponentene i et sammensatt begrep, bestående av fire (nært beslektede) kriterier som stater bruker til å evaluere alvorligheten av en ekstern trussel:

1. Samlede maktressurser: Ceteris paribus (latin: under ellers like forhold), jo større en stats totale maktressurser er, desto større er den potensielle trusselen den utgiør for andre, og desto mer sannsynlig er det at den fremprovoserer alliansedannelse mot seg selv (Walt, 1987, s. 22). Dette er den vanligste forståelsen av maktbalansemekanismen.

2. Geografisk nærhet: Det er en vanlig antagelse i geopolitikk at evnen til å utøve makt synker i takt med geografisk avstand. Derav følger at, ceteris paribus, stater giør sine valg av allianser i respons til potensielle trusler som ligger i nærheten heller enn som respons til noen lenger unna (Walt, 1987, s. 23).

3. Offensiv makt: Ceteris paribus, stater med stor offensiv makt - stater med evnen til å true uavhengigheten eller den territoriale integriteten til andre - er mer sannsynlige til å fremprovosere en motallianse enn de som, av en eller annen grunn, har mindre evne til å angripe andre (Walt, 1987, s. 24).

4. Aggressive intensjoner: Ceteris paribus, stater som oppfattes av andre som aggressive aktører i internasjonale affærer vil fremprovosere mer motbalansering. Med andre ord er oppfatninger av aggressive intensjoner (enten de er fornuftige eller ikke) nøkkelen til å forstå alliansebeslutninger. Ifølge Walt er dette det viktigste av de fire kriteriene (1987, s. 25).

Ved å bruke alle disse fire, altså ved å se på ubalanse av trussel som kilde til allianser heller enn kun ubalanse i makt, argumenterer Walt for at man vil få en åpenbar forbedring av den klassiske maktbalansemekanismen.

Videre identifiserer Walt $(1987$, s. 17) to distinkte veier som stater kan følge når de oppfatter en betydelig ekstern trussel. De kan enten balansere ved å alliere seg med andre mot den rådende trusselen, eller de kan hoppe på the bandwagon, som innebærer å alliere seg med trusselkilden for å unngå å bli angrepet selv. De fleste teoretikere innenfor realismen vil nok si at balansering er den vanligste av de to, men at stater som er veldig svake sammenlignet med trusselkilden kan være tilbøyelige til bandwagoning ved å slutte seg til trusselkilden selv. Dette er langt fra en ny ide: 
In international politics, nothing succeeds like success. Momentum accrues to the gainer and accelerates his movement. The appearance of irreversibility in his gains enfeebles one side and stimulates the other all the more. The bandwagon collects those on the sidelines. (Thompson, 1977, s. 20)

Stater kan ha to motiver for å velge bandwagoning framfor balansering (Walt, 1987, s. 21). For det første kan bandwagoning fungere som en form for forsoningspolitikk; det å slutte seg til en stat som er på vei til toppen demonstrerer velvilje, og vil minske sannsynligheten for at en skal bli angrepet selv. For det andre, hvis staten som er på vei mot toppen ser ut til å vinne, kan andre alliere seg med denne for å sikre seg en andel av seiersutbyttet (se også Schweller, 1994).

Balansering og bandwagoning indikerer drastisk forskjellige realiteter. Hvis balansering er det styrende prinsippet i verdenspolitikk, vil aggresjon være et dumt valg, da dette bare fører til motbalansering. Hvis derimot bandwagoning er det styrende prinsippet, vil dominerende adferd være den beste måten å få allierte. Feiloppfatninger av ens omgivelser hva gjelder denne dikotomien vil naturligvis kunne ha katastrofale følger for alle involverte parter. Å komme nærmere en forståelse av hvilken av disse realitetene vi lever $\mathrm{i}$, som må sies å være et av artikkelens mål, er derfor av ytterste viktighet.

Oppsummert ville Walt trolig sagt at graden av oppfattet trussel fra Kina har betydelig innvirkning på hvordan stater stiller seg til kinesiske initiativer og institusjoner. ${ }^{2}$ Derimot ville han ikke vært sikker på hvilken retning denne tendensen ville gått $\mathrm{i}$ - motbalansering av Kina (at stater blir mer avvisende til Huaweis 5G) eller bandwagoning med Kina (at stater blir mer aksepterende til selskapets rolle). Dette leder til artikkelens første hypotese, som for tydelighetens skyld er delt i to:

Hypotese 1a: Ceteris paribus, når en stat oppfatter en trussel (etter Walts definisjon) fra Kina, vil den staten bli mer avvisende til Huaweis $5 G$.

Hypotese 1b: Ceteris paribus, når en stat oppfatter en trussel (etterWalts definisjon) fra Kina vil den staten bli mer aksepterende til Huaweis $5 G$.

Carney med flere: Patron-klient-forhold med USA

Mesteparten av faglitteraturen om globalt lederskap deler en overbevisning om at formelle, bilaterale bånd er en forutsetning for en suksessfull leders innflytelse (Way \& Levitsky, 2007, s. 53-54; se også Schirm, 2010). Det er derfor tenkelig at det å ha formelle bånd til USA, som en lang liste av stater har, påvirker beslutningene som disse statene tar i rivaliseringen mellom USA og Kina.

Konseptet patron-klient-forhold oppstod først i antropologiske studier, som brukte det til å beskrive forholdet mellom ledere og følgere i bestemte stammer og

\footnotetext{
${ }^{2}$ Merk at ideen om at Kina er eksplisitt truende har nok av kritikere. I hvert fall er det mange som vil nyansere denne ideen. For eksempel argumenter Mahbubani (2020, s. 85-86) for at Kina har et "powerful antimilitary DNA». Se også Kang, 2007, 2010; Jacques, 2009; Johnston, 1995; Kissinger, 2011 for videre diskusjon rundt Kinas egenart.
} 
regioner. I slike forhold ga lederne spesifikke tjenester til sine subjekter i bytte mot deres lojalitet (Carney, 1989, s. 43). Fagfeltet internasjonale relasjoner har siden implementert disse tankene i sine egne teorier om forholdet mellom stater (f.eks. Lande, 1983; Shoemaker \& Spanier, 1984). Et grunnleggende prinsipp her er at jo flere klienter en patron har, desto videre blir dens maktbase. Hva gjelder oppførsel er samsvar (compliance) en sentral karakteristikk: «The patron expects compliance from the clients in matters of patronal interests» (Carney, 1989, s. 45). Samsvar kan måles på mange måter, men av særlig viktighet er "the client's policies toward the patron's primary adversary" (Carney, 1989, p. 52).

I moderne historie er det ingen stater som har behersket teknikken for å få venner og allierte like bra som USA. Siden andre verdenskrig har USA jobbet for å bygge og sementere et nettverk av venner og allierte verden over - et system av klienter der Washington er alles patron. Lake (2013) argumenterer for at underordnede stater i det han kaller contractual relationships gir opp visse aspekter ved sitt utenrikspolitiske selvstyre til USA i bytte mot sikkerhetsgarantien som bare Washington kan gi (se også Liska, 1978, s. 272). På visse måter kan man tenke på dette som USAs store fordel i kampen mot Kina (Brooks \& Wohlforth, 2016). ${ }^{3}$

I tillegg til å signere formelle alliansetraktater, kan en patron demonstrere sin forpliktelse til denne garantien på mange måter. To av hovedmåtene er stasjonering av amerikansk militære i en klientstat (Schelling, 1960/1980, kap. 8), og våpensalg til den (Sullivan et al., 2011). I denne artikkelen vil jeg dermed forvente at slike tiltak vil korrelere positivt med graden av samsvar fra USAs klienter i spørsmålet om $5 \mathrm{G}$.

Det jeg vil undersøke her, er med andre ord hvor solide USAs strategiske relasjoner til andre stater vil kunne tenkes å være hvis det kom til en mer intens konflikt eller til og med en krig med Kina. Handler disse forholdene simpelthen om instrumentalitet, eller inneholder de også elementer av lojalitet og affinity som binder klienter til sin patron? Mer generelt, i hvilken grad er allianser og vennskap på den internasjonale arenaen hugget i stein? (f.eks. Leeds \& Savun, 2007; Lemarchand \& Legg, 1972). Dette leder til artikkelens andre hypotese:

Hypotese 2: Ceteris paribus, når en stat har formelle bånd til USA, ser dem som sin patron, og baserer seg på Washingtons sikkerhetsgaranti, vil denne staten vare mer avvisende til Huaweis $5 G$.

Er USAs venner og allierte faktisk mer mottakelige for amerikansk press til å unngå kinesiske initiativer og institusjoner? Og kan USA egentlig være sikre på at deres mange venner og allierte ville støtte dem fullt ut i en konflikt?

\footnotetext{
${ }^{3}$ Dette betyr $i k k e$ at Kinas ledere alltid opererer alene. Som jeg også skrev om i innledningen har multilateralisme blitt en viktig del av Kinas vekst. Jeg tror likevel at det forventes mer USAs venner og allierte.
} 
Hirschman: Handel som verktøy for utenrikspolitisk innflytelse

I sitt toneangivende verk om utenrikspolitiske konsekvenser av handel beskriver Albert Hirschman (1945/1980) det politiske aspektet ved internasjonale handelsrelasjoner, og utforsker måter handel kan bli brukt som et maktredskap av dem som søker økning i nasjonal makt og innflytelse. Hovedargumentet for frihandelsteoretikerne er at det vil skape et vennskapsbånd mellom stater. For Hirschman blir dette $\mathrm{i}$ overkant utopisk, basert på «the belief that the dependence of A on B is roughly the same as the dependence of B on A» (1945/1980, s. 10). Dette, mener han, er aldri det faktiske tilfellet.

Et essensielt begrep i hans bok er handelsavhengighet, som han hevder skaper utenrikspolitisk konvergens. Jo mer handel det er mellom stater, desto dyrere blir forstyrrelser i dette forholdet. Begge sider har derfor insentiver til å gå sammen om utenrikspolitiske saker, da de frykter at disputter vil kunne komme i veien for fordelene ved handel. Med andre ord øker handelsavhengigheten en stats mottakelighet for eksterne krav, grunnet frykt for å miste markedstilgang og andre økonomiske fordeler. Dette gjør at økonomisk svakere stater justerer sine egne utenrikspolitiske interesser for å imøtekomme ønskene til de økonomisk sterkere statene (Dreher et al., 2008, s.150). Sagt med ordene til Hirschman selv: A kan forsterke sitt grep om $\mathrm{B}, \mathrm{C}$ eller $\mathrm{D}$ ved å skape en situasjon der disse statene vil godta alt for å holde på handelen de har med A (1945/1980, s. 17).

Hart \& Jones (2010) er blant dem som har anvendt Hirschmans teori direkte på det moderne Kinas praksis. De mener at Beijings handelsrelasjoner til svakere stater setter dem i svært fordelaktige posisjoner, der de kan bruke sine økonomiske pressmidler til å influere disse statene. I de fleste av disse tilfellene er Kina i en posisjon der de kan ta seg råd til å forlate forhandlingsbordet, som igjen setter dem $i$ en mye bedre forhandlingsposisjon enn en stat som vil lide stort hvis handelen forstyrres. På denne måten fungerer ujevnheter i handelsavhengighet som kraftfulle våpen i Kinas opparbeidelse av makt og innflytelse, ved å tvinge de svakerestilte partene til å gjøre utenrikspolitiske justeringer i møte med Beijing. Spørsmålet av interesse for denne artikkelen er hvorvidt slike handelsvåpen kan være nok til å få stater til å vende seg bort fra USA og mot Kina i spørsmålet om 5G. Dette leder til min tredje og siste hypotese, som i likhet med den første er todelt:

\footnotetext{
Hypotese 3a: Ceteris paribus, når en stat har tette handelsrelasjoner til Kina, legges denne staten under kinesisk innflytelse, som igjen vil gjøre staten mer aksepterende til Huaweis $5 G$.
}

Jeg antar videre at disse mekanismene er direkte overførbare til USA. Altså tror jeg at det å ha tette handelsrelasjoner til USA har en lignende, men motsatt effekt på staters posisjonering mellom de to supermaktene: 
Hypotese 3b: Ceteris paribus, når en stat har tette handelsrelasjoner til USA legges denne staten under amerikansk innflytelse, som igjen vil gjøre staten mer avvisende til Huaweis $5 G$.

Essensen i denne hypotesen er å sette krav om sikkerhet og overlevelse opp mot ønske om økonomisk vinning. Enhver strukturell realist vil selvsagt argumentere for at sikkerhetshensyn nærmest alltid trumfer økonomiske hensyn. Dermed vil artikkelens teoretiske logikk implisere at variablene som omhandler handelsrelasjoner vil ha liten effekt på den avhengige variabelen - i hvert fall en mye mindre effekt enn den som variablene i de to første modellene vil ha. Like fullt tror jeg det kan være spennende å undersøke dette selv. Det er en vanlig overbevisning $\mathrm{i}$ vårt samfunn at Kinas mest effektive våpen $\mathrm{i}$ kampen om innflytelse er dets økonomiske makt (f.eks. Economic Times, 2020; Ghosh, 2013). Er dette faktisk tilfelle?

\section{Data og metode}

Utvalg av stater til panelet

Jeg tar utgangspunkt i International Monetary Fund (IMF) sin toppliste over projisert bruttonasjonalprodukt (BNP) fra juni 2021 (Statistics Times, 2021). Jeg begrenser utvalget til om lag øvre tredjedel av listen, slik at jeg kun ser på stater som har en betydelig internasjonal tyngde. Dette er stater som virkelig betyr noe for USA og Kina fordi deres støtte, eller mangel på støtte, kan gjøre en betydelig forskjell i internasjonale strategiske sammenhenger.

Jeg starter med 75 stater, og tar vekk USA og Kina fra de to øverste plassene. Jeg utelater også tre andre stater fra panelet: Taiwan, Hong Kong og Puerto Rico. I Taiwans tilfelle er det diskutabelt hvorvidt det kan regnes som en uavhengig stat. For Hong Kong og Puerto Rico er uavhengighet ikke engang et relevant spørsmål. Når det gjelder posisjonering mellom USA og Kina blir disse tre møtt med et helt annet sett med muligheter og begrensninger enn det andre stater blir, og de er derfor ikke passende til artikkelens formål.

Jeg står igjen med et panel bestående av 70 stater som er, riktignok i varierende grad, fanget i midten av rivaliseringen mellom USA og Kina. En majoritet av statene er, igjen i varierende grad, USAs venner og allierte, enda det er mange av statene i utvalget som har mer nøytrale posisjoner. Panelet inneholder også noen stater som åpenbart lener seg mot Beijing, fortrinnsvis Russland og Iran (f.eks. Christensen, 2015, s. 134; Ellyatt, 2019; McGregor, 2019).

\section{Avhengig variabel}

Jeg har kodet den avhengige variabelen - Huaweis $5 G$ - på en skala fra 1 til 6, der 1 betegner en holdning som er fullstendig aksepterende til Huaweis 5G (som dermed 
gleder Kina og kan provosere USA til å sanksjonere mot denne staten), og 6 betegner en holdning som er fullt ut avvisende til selskapets rolle (som dermed gleder USA, men kan provosere Kina).

Tabell 1. De seks kategoriene i den avhengige variabelen

\section{Holdning til Huaweis 5G}

6 Fullt forbud: Landets myndigheter har nedlagt fullt forbud mot Huaweis utstyr i det nasjonale 5G-nettverket.

5 Betydelige statlige restriksjoner: Landets myndigheter har innført lover som utgjør store barrierer for Huawei, eller har inngått cybersikkerhetsavtaler med USA.

4 Operatører styrer unna: Noen av landets største telekomoperatører har gitt 5G-kontrakter til Ericsson, Nokia og/eller lokale aktører, og styrer med dette unna Huawei.

3 Åpen tilnærming: Landet ser til en viss grad bort fra USAs advarsler, og uttaler at de ikke vil utelukke noen leverandører fra byggingen av $5 \mathrm{G}$.

2 Framtidig bruk: Landet bruker Huawei aktivt i teknologien, for eksempel giennom 5G-tester. Selve 5G-implementeringen er i tidlige faser, men det meste peker mot full bruk i fremtiden.

1 Full bruk: Landets myndigheter bruker Huawei i $5 \mathrm{G}$ uten synlige restriksjoner, og nettverkene er allerede lansert eller like ved lansering.

To merknader er nødvendige før jeg fortsetter. For det første er det selvsagt flytende overganger mellom hver av disse kategoriene. Noen stater, som Australia og Japan, var tidlig ute med å nedlegge fulle forbud mot Huawei (Slezak \& Bogle, 2018; Tao, 2018). Andre, som Indonesia og Russland, har signert store nasjonale avtaler med Huawei (Jibiki \& Kawakami, 2020; Qingqing \& Yeping, 2020). Slike tilfeller gir tydelige holdepunkter, noe som gjør kodingen enklere, men i mange andre tilfeller er det svært lite som skiller en kategori fra den neste. Enkelte stater faller også mellom flere stoler, og har vært krevende å plassere - Irland, Mexico, Canada og Hellas kan nevnes her (Alley, 2020; Argue, 2021; Breakenridge, 2021; The National Herald, 2020). Andre, som Brasil og De forente arabiske emirater, er for tiden under hardt press fra USA om å droppe Huawei fra 5G, og er dermed også utfordrende å kategorisere (Mason \& Martina, 2021; Wadhams \& Westall, 2021). Trolig kan man diskutere i evigheter hvilken kategori en bestemt stat burde havne i. Jeg har fastsatt tabellen så presist jeg har klart, og mens lesere kan være uenige i mine vurderinger, har jeg tro på at dette er tilstrekkelig solide, ikke minst underbygde, kategoriseringer for artikkelens formål.

For det andre er holdningene til Huaweis 5G i konstant utvikling. Jeg har derfor satt en sluttdato for målingene mine på 15 . oktober 2021, men ting kan selvfølgelig ha endret seg ytterligere siden det. Jeg må ha denne muligheten for fortsatte endringer med meg i den videre diskusjonen av materialet. 
Tabell 2. De 70 statenes holdninger til Huaweis 5G, per 15. oktober 2021. Statene er sortert etter projisert BNP fra International Monetary Fund. ${ }^{4}$

\begin{tabular}{|c|c|}
\hline Stat & Holdning til Huaweis 5G \\
\hline Japan & 6: Nedla fullt forbud mot Huawei i 5G allerede i desember 2018. \\
\hline Tyskland & 5: Vedtok ny IT-sikkerhetslov i mai 2021 som gjør det vanskelig for Huawei å delta i $5 \mathrm{G}$. \\
\hline Storbritannia & $\begin{array}{l}\text { 6: Nedla fullt forbud mot Huawei i } 5 \mathrm{G} \text { i juli 2020, og krever utfasing av Huaweis utstyr } \\
\text { fra nettverket innen } 2027 \text {. }\end{array}$ \\
\hline India & 5: Har begynt gradvis utfasing av Huaweis utstyr fra 5G. Analyser spår et snarlig forbud. \\
\hline Frankrike & 5: Nasjonale selskaper har ikke fått fornye sine lisenser med Huawei etter juli 2020. \\
\hline Italia & $\begin{array}{l}\text { 5: Blokkerte en større 5G-avtale med Huawei i oktober } 2020 . \text { Ga en annen avtale } \\
\text { «betinget godkjennelse» i mai 2021, som innebar en ekstremt høy sikkerhetsterskel. }\end{array}$ \\
\hline Canada & 5: Avgjørelse avventes enda, men analyser spår et snarlig forbud mot Huawei i 5G. \\
\hline Sør-Korea & $\begin{array}{l}\text { 3: Står imot sterkt press fra USA om å forby Huawei, og har uttalt at det vil være opp til } \\
\text { hver enkelt operatør hvem de velger til å bygge sitt 5G-nettverk. }\end{array}$ \\
\hline Russland & 1: Lanserte 5G-nettverk i Moskva med Huawei i april 2021. \\
\hline Australia & 6: Nedla fullt forbud mot Huawei i 5G allerede i august 2018. \\
\hline Brasil & 2: Huawei har kjørt 5G-tester. USA presser hardt for et forbud, men Bolsonaro står imot. \\
\hline Spania & 4: Nasjonale telekomoperatører valgte Nokia og Ericsson til å bygge 5G i juni 2021. \\
\hline Mexico & $\begin{array}{l}\text { 3: Bruker Huawei i 5G. Riktignok med visse restriksjoner, men disse sies å være et } \\
\text { «kompromiss» for å prøve å holde USA tilfredse. }\end{array}$ \\
\hline Indonesia & 1: Signerte større 5G-avtale med Huawei i desember 2020. \\
\hline Nederland & $\begin{array}{l}\text { 5: Etter en større spionasje-avsløring i april 2020, har Huawei blitt utestengt fra landets } \\
5 \text { G i stadig større grad. }\end{array}$ \\
\hline Sveits & 1: Signerte større 5G-avtale med Huawei i mars 2020, til USAs store frustrasjon. \\
\hline Saudi-Arabia & 1: Valgte Huawei til å bygge $5 \mathrm{G}$ i oktober 2019. \\
\hline Tyrkia & 2: Kaller Huawei en "pålitelig forretningspartner», og har brukt selskapet til 5G-tester. \\
\hline Iran & $\begin{array}{l}\text { 2: USAs sanksjoner tvang Ericsson til å trekke seg ut av landet. Huawei har entret } \\
\text { scenen og fylt det teknologiske tomrommet. } 5 \mathrm{G} \text { er foreløpig ikke aktuelt. }\end{array}$ \\
\hline Polen & $\begin{array}{l}\text { 6: Signerte } 5 \mathrm{G} \text {-sikkerhetsavtale med USA, og har gitt ut en liste med strenge krav til } \\
\text { leverandører av mettverk som sies å gjøre det umulig for Huawei å bygge landets } 5 \mathrm{G} \text {. }\end{array}$ \\
\hline Sverige & $\begin{array}{l}\text { 6: Nedla fullt forbud mot Huawei i } 5 \mathrm{G} \text { i oktober 2020, og krever at Huaweis utstyr skal } \\
\text { fjernes fra nettverket innen } 2025 \text {. }\end{array}$ \\
\hline Belgia & $\begin{array}{l}\text { 5: Sperret for «høyrisikoleverandører» i } 5 \text { G i juni } 2020 \text {. Større 5G-kontrakt ble gitt til } \\
\text { Nokia i oktober 2020; et tegn på at sperren gjelder Huawei. }\end{array}$ \\
\hline Thailand & $\begin{array}{l}\text { 1: Huawei roste landet som «regionens } 5 \mathrm{G} \text {-ledere» i oktober } 2020, \text { og de to lovte } \\
\text { hverandre å fortsette samarbeidet om } 5 \mathrm{G} \text {. }\end{array}$ \\
\hline Nigeria & 2: Kjørte 5G-tester med Huawei i november 2019. \\
\hline Østerrike & $\begin{array}{l}\text { 3: Ser ut til å være nølende til å utelukke noe som helst. Har sagt at de «kanskje vil } \\
\text { vurdere» Huawei til sitt 5G-nettverk. }\end{array}$ \\
\hline
\end{tabular}

${ }^{4}$ Kontakt artikkelforfatter for en mer utfyllende beskrivelse av kodingen av den avhengige variabelen. 
Tabell 2. (forts.)

\begin{tabular}{|c|c|}
\hline Stat & Holdning til Huaweis $\mathbf{5 G}$ \\
\hline Irland & $\begin{array}{l}\text { 3: Landets største telekomoperatør har en større } 5 \mathrm{G} \text {-avtale med Huawei, som de har } \\
\text { uttalt at de vil holde på videre. Riktignok bruker de Ericsson i kjernen av } 5 \mathrm{G} \text {. }\end{array}$ \\
\hline Israel & 5: Huawei ble blokkert fra å delta i en viktig 5G-anbudsrunde i juni 2020 . \\
\hline Norge & $\begin{array}{l}\text { 4: Landets største telekomoperatør signerte en større 5G-kontrakt med Ericsson i } \\
\text { desember } 2019 .\end{array}$ \\
\hline Argentina & 1: Lanserte $5 \mathrm{G}$ med Huawei i sentral rolle i april 2021. \\
\hline Filippinene & 1: Per juli 2020 har landets to største telekomoperatører lansert 5G med Huawei. \\
\hline $\begin{array}{l}\text { De forente } \\
\text { arabiske emirater }\end{array}$ & $\begin{array}{l}\text { 1: Valgte Huawei til } 5 \mathrm{G} \text { i oktober } 2019 \text {. For tiden truer USA med å kutte handelsavtaler } \\
\text { hvis de ikke forbyr det kinesiske selskapet. Det er fortsatt uklart hva utfallet blir. }\end{array}$ \\
\hline Egypt & 2: Har et tett samarbeid med Huawei på flere områder, selv om $5 \mathrm{G}$ fortsatt er i startgropa. \\
\hline Danmark & $\begin{array}{l}\text { 5: Vedtok ny sikkerhetslov som hever terskelen for at utenlandske selskaper skal få } \\
\text { involvere seg i teknologiske prosjekter i mai } 2021 \text {. }\end{array}$ \\
\hline Malaysia & $\begin{array}{l}\text { 4: Større 5G-kontrakt ble gitt til Ericsson i juli 2021, noe som utgjorde et stort strategisk } \\
\text { skifte vekk fra Huawei. }\end{array}$ \\
\hline Singapore & 4: Landets to største telekomoperatører valgte Ericsson og Nokia til å bygge $5 \mathrm{G}$ i juni 2020. \\
\hline Bangladesh & 1: Per oktober 2021 meldes det at 5G-lansering med Huawei er nært forestående. \\
\hline Vietnam & $\begin{array}{l}\text { 4: I januar } 2020 \text { sa landets største telekomoperatør at de vil bygge sitt eget } 5 \mathrm{G} \text {-nettverk, } \\
\text { fritt for Huaweis utstyr. }\end{array}$ \\
\hline Sør-Afrika & 1: Huawei lanserte landets 5G-nettverk i juli 2020. \\
\hline Chile & $\begin{array}{l}\text { 3: Landets myndigheter har latt døren stå åpen for Huawei, ved å si at de vil kjøpe } \\
\text { 5G-utstyr fra enhver som møter «visse tekniske standarder». }\end{array}$ \\
\hline Finland & 5: Vedtok 5G-sikkerhetslov som utgjør store barrierer for Huawei i desember 2020. \\
\hline Colombia & 2: Har uttalt at de ikke vil forby Huawei, som også kjørte 5G-pilot i mai 2020. \\
\hline Pakistan & 2: Har arbeidet tett med Huawei i årevis. Dog er $5 \mathrm{G}$ på et svært tidlig stadium. \\
\hline Romania & 6: Vedtok lov som eksplisitt forbyr Huawei fra 5G i mai 2021. \\
\hline Tsjekkia & $\begin{array}{l}\text { 5: Signerte } 5 \text { G-sikkerhetsavtale med USA i mai } 2020 \text {. Huawei ble stengt ute fra en viktig } \\
\text { anbudsrunde for } 5 \text { G-kontrakter i september } 2020 \text {. }\end{array}$ \\
\hline Portugal & $\begin{array}{l}\text { 4: Landets tre største telekomoperatører annonserte i juli } 2020 \text { at de vil styre unna } \\
\text { Huawei i 5G-kjernen. }\end{array}$ \\
\hline New Zealand & $\begin{array}{l}\text { 4: Landets myndigheter har uttalt at de ikke vil forby Huawei offisielt, men landets to } \\
\text { største telekomoperatører arbeider med Nokia for } 5 \mathrm{G} \text {. }\end{array}$ \\
\hline Peru & $\begin{array}{l}\text { 2: Huawei kjørte 5G-tester i mai } 2019 \text {. Opplever et økende press fra USA om å gå en } \\
\text { annen vei, men det ser foreløpig ikke ut til å ha noen effekt. }\end{array}$ \\
\hline Hellas & 4: Landets største telekomoperatør valgte Ericsson til å bygge 5G i mars 2020. \\
\hline Irak & 2: Har jobbet tett med Huawei i årevis, men ikke foreløpig på 5G. \\
\hline Kazakhstan & 1: I mars 2021 meldte Huawei at de var klare til å lansere landets 5G. \\
\hline Qatar & 1: Valgte Huawei som partner til å bygge 5G i mars 2020. \\
\hline Ungarn & 1: Signerte større 5G-avtale med Huawei i oktober 2021. \\
\hline Ukraina & $\begin{array}{l}\text { 2: Huawei kjørte 5G-tester i oktober 2021. Landet signerte en kontroversiell } \\
\text { 5G-sikkerhetsavtale med Huawei i oktober } 2020 .\end{array}$ \\
\hline Algerie & $\begin{array}{l}\text { 2: Har flere teknologi-avtaler med Huawei, men landets myndigheter har uttalt at de vil } \\
\text { prioritere å styrke } 4 \mathrm{G} \text { før de begynner med } 5 \mathrm{G} \text {. }\end{array}$ \\
\hline
\end{tabular}




\begin{tabular}{|c|c|}
\hline Stat & Holdning til Huaweis 5G \\
\hline Kuwait & 1: Huawei ble valgt som hovedleverandør til 5G i mars 2020. \\
\hline Marokko & 1: I januar 2020 meldte Huawei at de var klare for å lansere landets 5G-nettverk. \\
\hline Slovakia & 5: Signerte 5G-sikkerhetsavtale med USA i oktober 2020. \\
\hline Cuba & $\begin{array}{l}\text { 2: Har foreløpig ikke begynt på } 5 \mathrm{G} \text {, men Huawei er involvert på flere andre teknologiske } \\
\text { områder. Havanna har uttalt at de har «full tiltro» til selskapet. }\end{array}$ \\
\hline Ecuador & $\begin{array}{l}\text { 4: Landets største telekomoperatør valgte Nokia til å bygge } 5 \mathrm{G} \text { i mars } 2021 \text {. Dette kom } \\
\text { etter økonomisk hjelp fra Washington til å holde Huawei ute. }\end{array}$ \\
\hline Kenya & 1: Landets største telekomoperatør lanserte 5G med Huawei i mars 2021. \\
\hline Etiopia & 1: Landets telekom-monopol har lovet å lansere 5G med Huawei i løpet av 2022. \\
\hline Sri Lanka & 2: Samarbeider tett med Huawei, som blant annet er valgt ut til å kjøre 5G-tester. \\
\hline $\begin{array}{l}\text { Den } \\
\text { dominikanske } \\
\text { republikk }\end{array}$ & $\begin{array}{l}\text { 2: Annonserte i februar } 2021 \text { at de ikke vil utelukke Huawei fra den kommende } \\
\text { anbudsrunden for 5G-kontrakter, som er satt til november } 2021 \text {. }\end{array}$ \\
\hline Guatemala & $\begin{array}{l}\text { 2: } 5 \mathrm{G} \text { er i tidlig fase, men Huawei er tungt involvert i tidligere generasjons nettverk. } \\
\text { Huawei donerte et telekommunikasjonstårn til landet i oktober } 2020 \text {. }\end{array}$ \\
\hline Myanmar & 2: 5G er i tidlig fase, men Huawei kjørte 5G-tester i landet i juni 2019. \\
\hline Oman & 1: I februar 2020 fikk Huawei offisielt grønt lys til å bygge landets 5G. \\
\hline Luxemburg & 4: Landets største telekomoperatør valgte Nokia til å bygge 5G i desember 2020. \\
\hline Bulgaria & 5: Signerte 5G-sikkerhetsavtale med USA i oktober 2020. \\
\hline Angola & $\begin{array}{l}\text { 2: } 5 \mathrm{G} \text { er enda i startgropa, men Huawei har en sterk tilstedeværelse i landet, og står bak } \\
\text { store investeringer innen teknologi. }\end{array}$ \\
\hline Ghana & 2: Huawei sponser en rekke teknologiske prosjekter i landet, men foreløpig ikke 5G. \\
\hline
\end{tabular}

Uavhengige variabler

De uavhengige variablene - de potensielle forklaringene bak variasjonene i tabellen over - deles i tre grupperinger, som alle korresponderer med en av de teoretiske grenene jeg gikk gjennom tidligere. I første gruppering operasjonaliserer og måler jeg tre av Walts fire komponenter av trusseloppfatning (den fjerde av komponentene oppfattede aggressive intensjoner - er nærmest umulig å operasjonalisere). For variabelen samlede maktressurser relativt til Kina (MaktRelKina) bruker jeg Correlates of War Project sin liste over National Material Capabilities. Her bruker jeg de nyeste tilgjengelige tallene i versjon 6.0, som er fra 2016 (opprinnelig fra Singer, 1988). Merk at jeg legger inn alle statenes tall som prosentandel av Kinas tall på 0,2306. For variabelen geografisk nærhet fra en stats hovedstat til Beijing (AvstandKina) bruker jeg en distanse-kalkulator på nett som gir meg great circle distance fra Beijing til de andre hovedstedene. For variabelen offensiv makt relativt til Kina (OffMaktRelKina), bruker jeg listen fra Global Fire Power (2021a), der jeg igjen omregner til prosentandel av Kinas tall på 0,0854.

I andre gruppering av uavhengige variabler operasjonaliserer og måler jeg tre sentrale indikatorer på staters patron-klient-forhold med USA. Variabelen allianse med USA (AllianseUSA) har fire kategorier: $1=$ medlemskap i NATO, $2=$ sentrale allierte utenfor NATO, $3=$ strategisk partnerskap med USA, $4=$ ingen allianse. 
Data på allierte er hentet fra U.S. Department of State (2021), og data på strategiske partnerskap er hentet fra Hamilton (2014, s. 22-23). For variabelen antall utplasserte fra USAs militære (MilitereUSA), bruker jeg data fra US Defense Manpower Data Center (2021), med tall fra juni 2021. Merk at denne variabelen er sterkt forskjøvet mot høyre; mens USA kun har utplassert en håndfull tropper $\mathrm{i} \mathrm{de}$ fleste statene på panelet, har de tusenvis i noen få av stater. For å minimere denne effekten bruker jeg denne variabelens naturlige logaritme (LnMilitcereUSA). For variabelen våpenimport fra USA (VåpenImportUSA) bruker jeg Stockholm International Peace Research Institute $\sin$ Arms Transfers Database til å kalkulere hvilke prosenter av en stats totale våpenimport som kommer fra USA (SIPRI, 2021). For å ta høyde for statistisk uteliggende år bruker jeg gjennomsnittet av tallene fra perioden 2015-2020.

I tredje gruppering av uavhengige variabler måler jeg utvalgte sider av staters handelsrelasjoner til henholdsvis Kina og USA. Jeg har hentet tallene for import fra Kina (ImportKina), import fra USA (ImportUSA) eksport til Kina (EksportKina) og eksport til USA (EksportUSA) fra Verdensbankens World Integrated Trade Solution (World Bank, 2021). Her bruker jeg de nyeste tilgjengelige dataene, som for de fleste statene (med noen få unntak) er fra 2018. Alle tall er lagt inn som prosent av den aktuelle statens totale import og eksport.

\section{Analyse}

Første bivariate modell: Effekten av trusseloppfatning fra Kina

Tabell 3. Korrelasjonene mellom de tre variablene i trusseloppfatning og holdninger til Huaweis $5 \mathrm{G}$

\begin{tabular}{lcccc}
\hline & Huaweis5G & MaktRelKina & AvstandKina & OffMaktRelKina \\
\hline Huaweis5G & 1,0000 & & & \\
MaktRelKina & 0,1063 & 1,0000 & & \\
AvstandKina & $-0,0873$ & $-0,2416$ & 1,0000 & \\
OffMaktRelKina & 0,1443 & 0,7830 & $-0,2728$ & 1,0000 \\
\hline
\end{tabular}

To av disse variablene - samlede maktressurser relativt til Kina (MaktRelKina) og offensiv makt relativt til Kina (OffMaktRelKina) har tydelige positive korrelasjoner med den avhengige variabelen; når de øker, økerY. Dette tyder på at, ceteris paribus, jo mer en stats totale eller offensive makt nærmer seg Kinas, desto mer avvisende blir denne staten til Huaweis $5 \mathrm{G}$.

Den tredje av variablene viser motsatt effekt: Geografisk nærhet til Beijing (AvstandKina) har en svak negativ sammenheng med staters holdninger til Huaweis 5G. Denne tyder altså på at stater som ligger geografisk lenger unna Beijing, blir stadig mer aksepterende til Huaweis $5 \mathrm{G}$. Som en robusthetssjekk for variabelen lager jeg en dikotom variabel for Kinas naboer, der jeg bruker 6000 kilometer som 
en skillelinje (NaboKina). Her snur sammenhengen igjen; statene innenfor Kinas geografiske region er generelt langt mer aksepterende til Huaweis $5 \mathrm{G}(2,353)$ enn statene utenfor samme region $(3,226)$. Geografisk nærhet til Kina har altså ingen entydig sammenheng med staters holdning til Huaweis 5G, og resultatet fra disse variablene må derfor tolkes med betydelig forsiktighet.

Oppsummert gir to av tre variabler i denne modellen klare styrkende beviser for hypotese $1 \mathrm{~b}$; ceteris paribus, stater som etter Walts definisjon av begrepet skal føle seg mindre truet av Kina blir mer avvisende til Huaweis 5G, mens de som etter definisjonen skal føle seg mer truet blir mer aksepterende til selskapets rolle. Den tredje variabelen om geografisk nærhet taler for hypotese $1 \mathrm{a}$, altså det motsatte, men denne sammenhengen svekkes betraktelig av sin robusthetssjekk, som i stedet taler for hypotese $1 \mathrm{~b}$.

Slik det alltid vil være i analyser som denne, er det åpenbare unntak fra mønsteret. Vietnam er ett eksempel; til tross for at det er Kinas nabo og til tross for at dets makt er forsvinnende liten i forhold til Kina (Vietnam bør altså, per Walts definisjon, oppleve en sterk trussel fra Kina), er denne staten relativt avvisende til Huaweis 5G, og har i stedet brukt lokale tilbydere til å bygge sitt nasjonale 5G-nettverk (Onishi, 2020). Listen med lignende eksempler er lang, noe som illustrerer at en rekke kontekstuelle faktorer ut over mine variabler kan være med på å bestemme hvordan stater stiller seg mellom USA og Kina i spørsmålet om 5G. Statistisk uteliggende stater, som Vietnam, illustrerer dermed også en viktig svakhet i min statistiske tilnærmingsmåte; jeg vil uunngåelig ha vanskeligheter med å få fram den høyst reelle kompleksiteten i disse temaene. Jeg oppfordrer derfor kommende forskere til å se videre på statene i mitt panel fra et mer kvalitativt perspektiv enn jeg har mulighet til her - hvorfor stiller de seg som de giør?

Når det gjelder spørsmålet om balansering indikerer resultatene i denne modellen at de statene som er svakest i møte med Kina har en tendens til å hoppe på Kinas bandwagon, mens de mektigere - de som har makt til å stå opp mot Kina på ulike måter - har en tendens til å balansere mot dem. Igjen finnes det selvfølgelig alternative tolkninger her. Stater som ved første øyekast ser ut til å være på Kinas bandwagon kan muligens, i hvert fall i noen grad, i realiteten bruke Kina som en måte å balansere mot USA. Malaysia er muligens et eksempel på dette; i en årrekke har dets statsminister, Mahathir Mohamed, gientatte ganger advart om farene ved unilateralisme, konfrontert USA for deres "playground tactics of control", og understreket behovet for å opprettholde "a level playing field" (f.eks. Saddiq, 2019; Wallace, 1992). ${ }^{5}$ Spørsmålet kan reises om flere stater tenker på denne måten. Dette spørsmålet faller utenfor artikkelens rekkevidde, men det er utvilsomt en interessant tanke å ta med seg videre.

\footnotetext{
${ }^{5}$ Det bør nevnes at Malaysia nylig gjorde en helomvending på dette området, da en nasjonal 5G-kontrakt ble gitt til Ericsson i juli 2021. Dette utgjorde et større strategisk skifte bort fra Huawei (Lennighan, 2021).
} 
Andre bivariate modell: Effekten av å ha USA som patron

Tabell 4. Gjennomsnittsholdningene til Huaweis $5 \mathrm{G}$ ut fra type allianse med USA

\begin{tabular}{lccc}
\hline & Observasjoner & Spenn, min.-maks. & Huaweis5G \\
\hline NATO & 20 & $1-6$ & 4,550 \\
Allianse utenfor NATO & 13 & $1-6$ & 2,692 \\
Strategisk partnerskap & 21 & $1-6$ & 2,714 \\
Ingen allianse & 16 & $1-4$ & 1,688 \\
\hline
\end{tabular}

Denne variabelen har forholdsvis sterke effekter: Medlemmer av NATO er langt mer avvisende til Huaweis $5 \mathrm{G}$ enn stater som står uten noen allianse. USAs allierte utenfor NATO og dets strategiske partnere er også merkbart mer avvisende enn statene uten allianse, enda denne effekten er ganske mye mindre. Slår jeg sammen alle stater med noen form for allianse er disse også mye mer avvisende $(3,319)$ til Huaweis $5 \mathrm{G}$ enn stater uten noe tilsvarende bånd til USA $(1,688)$.

En annen ting å merke seg er at i de tre første kategoriene varierer holdningene fra 1 til 6, som illustrerer at for alle typer allianse med USA finnes det enkeltunntak til den generelle tendensen. Ungarn er ett av disse; det ser ut til å være fullt ut aksepterende til Huaweis 5G på tross av sitt medlemskap i NATO (Global Times, 2021). Langs tilsvarende linje har Huawei stor suksess med $5 \mathrm{G}$ blant USAs venner i MidtØsten (AFP, 2021). Unntakene er derimot færre for stater uten noen formelle bånd til USA; her går variasjonen kun mellom 1 og 4 , som vil si at ingen av disse statene har gått særlig hardt ut mot det kinesiske selskapet. Dette styrker funnet om at det å ha USA som patron er med på å trekke stater unna Huaweis 5G.

Tabell 5. Korrelasjonene mellom to aspekter av patron-klient-forhold med USA og holdninger til Huaweis $5 \mathrm{G}$

\begin{tabular}{lccc}
\hline & Huaweis5G & LnMilitareUSA & VapenImportUSA \\
\hline Huaweis5G & 1,0000 & & \\
LnMilitcreUSA & 0,3357 & 1,0000 & \\
VåpenImportUSA & 0,2295 & 0,4340 & 1,0000 \\
\hline
\end{tabular}

Begge disse korrelasjonene er imponerende sterke. Ceteris paribus, jo flere utplasserte fra sitt militære USA har stasjonert i en stat (med naturlig logaritme, LnMilitcereUSA), desto mer avvisende er denne staten til Huaweis 5G. Som en robusthetssjekk undersøker jeg om den samme trenden opprettholdes hvis jeg ser på utplasserte fra USAs militære som prosentandel av statens totale militære styrker (listen Available Military Manpower fra Global Fire Power (2021b).Denne korrelasjonen er også positiv, om enn noe svakere $(0,1890)$, som helt klart styrker resultatet ytterligere. På tilsvarende måte ser vi at, ceteris paribus, jo større andel av en stats våpenimport som kommer fra USA (VäpenImportUSA), desto mer avvisende er denne staten til selskapets rolle i 5G. 
Sett under ett gir denne modellen sterke styrkende beviser til hypotese 2; ceteris paribus, de statene som ser USA som sin patron og som baserer seg på Washingtons sikkerhetsgaranti er mer avvisende til Huaweis $5 \mathrm{G}$ enn de som står mer alene. Patron-klient-teorien ser altså ut til å være høyst relevant for spørsmålet om $5 \mathrm{G}$. Det kan være mange grunner til dette; én kan være at Washingtons klienter er de primære målene i USAs presskampanje - at de er mottakere av det mest intense presset. Da Storbritannia opprinnelig bestemte seg for å la Huawei bygge deler av sitt 5G, ble det meldt om at daværende president Trump ringte Storbritannias statsminister Boris Johnson «in apoplectic fury» og beskyldte ham for forræderi (Bienkov, 2020) Som vi nå vet, reverserte Storbritannia etter hvert sin holdning til Huawei (Sandle \& Faulconbridge, 2020). Følger vi resultatene fra denne modellen, spilte Londons avhengighet av Washington en sentral rolle i avgjørelsen om å snu.

Når det gjelder balansering, ser det ut som Washingtons klienter har en tendens til å samle seg rundt USA for å balansere mot Kina, mens de som står mer på egenhånd tenderer til bandwagoning med Kina. Som i den forrige modellen, er det selvsagt alternative tolkninger her. Ikke bare kan de vi tenker på som Kinas bandwagoners faktisk drive med motbalansering av USA (som jeg foreslo i diskusjonen rundt Malaysia), og de statene vi tenker at balanserer mot Kina kan også ha visse elementer av bandwagoning med USA - at de statene som er strengest mot Huawei slutter seg til Washingtons side med et (sekundært?) motiv om å unngå å pådra seg amerikansk harme. Uansett tolkning tydeliggjør både første og andre modell det samme; fordi vi må behandle staters sanne intensjoner som ukjente, kan vi aldri vite sikkert hva som foregår i verden når det det kommer til alliansepolitikk og balansering.

Tredje bivariate modell: Effekt av handelsrelasjoner

Tabell 6. Korrelasjonene mellom staters handelsrelasjoner med Kina og USA og deres holdninger til Huaweis $5 \mathrm{G}$

\begin{tabular}{lccccc}
\hline & Huaweis5G & ImportKina & EksportKina & ImportUSA & EksportUSA \\
\hline Huaweis5G & 1,0000 & & & & \\
ImportKina & $-0,3792$ & 1,0000 & & & \\
EksportKina & $-0,0537$ & 0,4906 & 1,0000 & & \\
ImportUSA & $-0,0489$ & 0,1121 & 0,0266 & 1,0000 & \\
EksportUSA & 0,0617 & 0,1338 & $-0,0611$ & 0,8603 & 1,0000 \\
\hline
\end{tabular}

Disse resultatene er, totalt sett, mindre overbevisende enn resultatene fra de to forrige modellene. Import fra Kina (ImportKina) utviser riktignok en distinkt negativ korrelasjon med den avhengige variabelen; det kan altså se ut som om, ceteris paribus, jo mer en stat importerer fra Kina, desto mer aksepterende er denne til Huaweis 5G. Dette er i tråd med hypotese 3a. Dog, for eksport til Kina (EksportKina) er korrelasjonen kun så vidt under 0 , som kan tyde på at effekten av import fra Kina godt kan være tilfeldig. Som jeg har diskutert tidligere, er datasettet sårbart for spuriøse effekter, 
og jeg ser derfor dette som en plausibel forklaring på ImportKina sin tilsynelatende styrke. Videre ser jeg at hverken import fra USA (ImportUSA) eller eksport til USA (EksportUSA) har noen betydelig korrelasjon med staters holdninger til Huaweis $5 \mathrm{G}$.

Oppsummert gir denne tredje modellen noe støtte til hypotese 3a, om at handel med Kina giør stater mer aksepterende til Huaweis 5G, og den gir ingen støtte til hypotese 3b, om at handel med USA gjør stater mer avvisende til selskapet. Det kan altså virke som om Hirschman overskygges av andre forskere i dette tilfellet. Som i de to andre modellene, kan vi finne enkelttilfeller i begge ender av skalaen. I tråd med den hypotetiserte effekten ser Russland, som handler mye med Kina og svært lite med USA, ut til å være fullt ut aksepterende til Huaweis 5G. Australia er i den andre enden; selv om de handler mye mer med Kina enn med USA, har de nedlagt fullt forbud mot Huawei, noe som taler Hirschmans teori midt imot. I motsetning til i de to første modellene, er det derimot ingen generell trend i denne som er nok til å overstyre slike enkelttilfeller.

Et interessant eksempel er Storbritannia, som innførte et fullt forbud mot Huawei i juli 2020 (Sandle \& Faulconbridge, 2020). Dette gjorde selvsagt Kina svært misfornøyd, men det var til stor glede for USA, britenes patron. På grunn av dette forbudet får Storbritannia visstnok en mye lengre og mye dyrere vei til 5G. Dette er altså enda et eksempel på at det å utvise lojalitet og samsvar til ens patron veier tyngre enn (kortsiktig) økonomisk vinning.

Selvsagt kan jeg ikke fullt ut avskjedige handelseffekt basert på dette funnet; for det er datasettet altfor lite. Det jeg kan si, er at det kan se ut som om økonomiske faktorer er mindre viktige enn makt og allianser for å forklare staters holdninger til Huaweis 5G. I tillegg ser vi her at bivariat analyse har åpenbare svakheter. Stater i Asia og stillehavsområdet, for eksempel, har av åpenbare geografiske grunner bred handel med Kina. Samtidig er noen av disse - som Australia - generelt skeptiske til Kinas ambisjoner, og særlig til Huaweis investeringer.

Her kunne jeg hatt god bruk for multivariat modellering, for å løsne opp i denne floken og se hvordan effektene samvirker. Dog blir en slik framgangsmåte i stor grad giort uegnet av artikkelens lave $N$, i kombinasion med at den avhengige variabelen kun har seks kategorier. Med forbehold om at vi ikke skal lese for mye inn i dette, prøvde jeg likevel noen runder med multivariat regresjon som en tilleggssjekk. For å beholde noen frihetsgrader begrenset jeg antallet variabler i hver regresjon, og testet heller mange modeller med ulike kombinasjoner av de uavhengige variablene.

Dette resulterte i styrking av min tentative konklusjon om at patron-klientteorien tilbyr den mest plausible forklaringen på staters holdninger til Huaweis 5G. Fem av variablene var som oftest signifikante og i forventet retning kontrollert for andre variabler, blant andre staters våpenimport fra USA (VåpenImportUSA) og en dummyversion av alliansevariabelen (DikotomAllianseUSA), som skiller mellom de tre første alliansekategoriene på den ene siden og de uten noe bånd på den andre. I tillegg var dummyvariabelen for Kinas naboer (NaboKina), import fra Kina (ImportKina) og eksport fra USA (EksportUSA) lovende, noe som kan tyde på at alle de 
tre teoretiske retningene jeg har brukt i artikkelen kan ha sitt å si for hvordan stater stiller seg til Huaweis 5G. Riktignok har jeg skrevet i de bivariate modellene at disse variablene må tolkes med forsiktighet, og det er derfor først og fremst patron-klientteorien som står styrket igjen som den mest tungtveiende forklaringen.

\section{Konklusjon}

Under administrasjonen til Donald Trump kan USA sies å ha forlatt de tidligere forsøkene på engagement med Kina og å ha ført en politikk med intens strategisk konkurranse - kanskje til og med containment i tradisjonell Kennan-stil (f.eks. Campbell \& Sullivan, 2019; Small, 2019). Det kan også se ut som president Joe Biden kommer til å følge samme linje; det ser ut til å være bred tverrpolitisk enighet i Kongressen om at Kina utgiør en alvorlig trussel mot USA og resten av verden (f.eks. Browne, 2017; Walt, 2020).

Verdens sekundære stater har, riktignok i varierende grad, havnet i klem mellom de to supermaktene. Likevel er disse absolutt ikke tappet for autonomi; "[m]any countries and regions have become big enough to walk away from both America and China. Most countries have also become shrewder at weighing and acting on their own geopolitical interests» (Mahbubani, 2020, s. 213). På lignende måte påpeker Ikenberry $(2015$, s. 3) hvordan verdens middle states ofte har sterke grunner til å ønske at dagens stormaktsdualitet skal fortsette, da dette kan la dem fortsette å nyte $b a ̊ d e$ sikkerhetsfordelene ved å alliere seg med USA $o g$ de økonomiske fordelene av å holde seg inne med Kina.

Selv om det altså kan sies at de på flere vis står godt i dagens situasjon, er det en realitet at verdens små og mellomstore stater støtt og stadig presses til å giøre vanskelige valg mellom USA og Kina. I denne artikkelen har jeg sett nærmere på en av de mange konfliktområdene som verden har måttet ta stilling til de siste årene; Huawei og dets rolle i implementering av 5G. Jeg spurte hvilke faktorer som har innvirkning på hvordan 70 stater posisjonerer seg til selskapets $5 \mathrm{G}$, og lette etter mulige forklaringer i tre grener av politisk realisme. Fra disse utledet jeg et sett av hypoteser og potensielt relevante forklaringsvariabler.

Gjennom tre runder med bivariat analyse oppdaget jeg noen tydelige mønstre. For det første, i samsvar med Walts teori om hvordan oppfattet trussel presser fram allianser, fant jeg at de statene som blir forsvinnende små i møte med Kinas samlede $o g$ offensive makt - de som ifølge Walt bør føle seg mer truet av Kina - var mer aksepterende til Huaweis 5G. Geografisk nærhet så først ut til å tale for det motsatte; at stater lenger unna Beijing - de som ifølge Walt bør føle seg mindre truet av Kina - ble stadig mer aksepterende til Huaweis 5G, men en robusthetssjekk av denne variabelen snudde tendensen tilbake til det de to andre variablene viste. Altså finner jeg enkelte beviser for hypotese $1 \mathrm{~b}$; det å oppfatte trussel fra Kina gjør stater mer aksepterende til Beijings voksende innflytelse, representert ved Huaweis rolle i 5G-implementering. 
For det andre, i samsvar med patron-klient-teoriens tanker om hvordan lojalitet og samsvar leder til utenrikspolitisk konvergens, er de statene som ser på USA som sin patron - som enten har en alliansetraktat eller et strategisk partnerskap med USA, er avhengig av våpenimport fra Washington, eller som har store tilstedeværelser av amerikansk militære - langt mer avvisende til Huaweis 5G, ceteris paribus. Disse funnene gir sterk støtte til hypotese 2 ; det å ha USA som patron gjør stater mer avvisende til selskapets rolle.

For det tredje, Hirschmans teori om hvordan økonomisk makt kan brukes som et verktøy for å øke innflytelsen viste seg å ha mindre innvirkning enn jeg hadde trodd da jeg satte opp hypotesene. Bare staters import fra Kina hadde betydelig påvirkningskraft på staters holdninger til Huaweis $5 \mathrm{G}$, mens de andre variablene av lignende type viste seg å ha minimale effekter. Dermed ble bare litt støtte gitt til hypotese $3 \mathrm{a}$, om at Kinas handelspartnere blir mer aksepterende til Huaweis 5G, mens enda mindre ingenting - ble gitt til hypotese 3b, om at USAs handelspartnere blir mer avvisende. Av de tre er det altså patron-klient-teorien som står igjen som den sterkeste forklaringen.

Som jeg har påpekt flere ganger gjennom artikkelen kan man identifisere enkeltunntak til hvert av disse funnene, som ofte gjør det uklart om det pekes mot balansering eller bandwagoning. Likevel kan en overordnet trend bli identifisert; de sterkere statene, de som er i stand til å forsvare seg selv og/eller de som kan lene seg på USA for støtte tenderer til motbalansering av Kina, mens de svakere statene og/eller de som står uten hjelp fra USA tenderer mot bandwagoning med Kina isteden.

Som jeg har nevnt flere ganger tidligere bør disse resultatene bli lest og tolket med forsiktighet. Dette av fire primære grunner. For det første, som ble tydeliggjort i analysen, er dette en utrolig kompleks tematikk, og jeg kan umulig dekke alle tenkelige aspekter av den. Det kreves en nærmest uendelig liste av forklaringsvariabler for å fange opp hele bildet, og man må derfor anta at det er faktorer utenfor de jeg har undersøkt som har innvirkning på staters holdninger til Huaweis 5G.

For det andre, som jeg skrev i metodekapittelet, kan holdningene jeg har brukt som grunnlag gjennomgå små og store endringer til enhver tid. Staters posisjonering i verdenspolitikken vil med andre ord gi så flyktige mål at jeg ikke vil kunne si med sikkerhet hvor relevante disse funnene vil være i kommende år.

For det tredje, som jeg nevnte allerede i introduksjonen, er en viktig svakhet ved min tilnærming, som i stor grad er kvantitativ, at jeg i for liten grad får mulighet til å grave i tematikkens betydelige kompleksitet. Mange enkelttilfeller passer rett og slett ikke inn i artikkelens fastsatte kategorier, men å utforske alle går langt utenfor artikkelens rekkevidde. Derfor oppfordrer jeg, som nevnt tidligere, videre forskning til å gjøre kvalitative dypdykk inn i artikkelens enkelttilfeller.

Den fjerde og siste grunnen er at et datasett bestående av 70 observasjoner knapt nok kvalifiserer som medium- $N$, og det er generelt for lite til å trekke definitive konklusjoner ut fra. Denne utfordringen er nok spesielt problematisk ettersom mine tre hypoteser ikke er gjensidig utelukkende. Korrelasjonene jeg finner i denne artikkelen er i høyeste grad sårbare for spuriøse effekter og andre systemiske eller 
tilfeldige feil. Derfor har jeg enda en oppfordring til fremtidige forskere om å bygge på fundamentet jeg legger her, for eksempel ved å utvide det til å dekke flere stater, flere uavhengige variabler og/eller flere kinesiske initiativer som kan fungere som illustrasjoner på rivaliseringen som stater i dag finner seg selv i midten av.

\section{Om forfatteren}

Øystein S. Christie har mastergrad i statsvitenskap fra NTNU i Trondheim, der han nå jobber som forskningsassistent. Hans interessefelt inkluderer internasjonal politikk, alliansedynamikk, samt amerikansk og kinesisk utenrikspolitikk.

\section{Takk}

Forfatteren ønsker å takke Hedda Giertsen og Jo Jakobsen for uvurderlige kommentarer underveis i prosessen. Eventuelle feil og mangler i den ferdige artikkelen er mitt ansvar.

\section{Referanser}

AFP. (2021, 25. februar). Huawei, controversial in the West, is going strong in the Gulf. Economic Times. https:// economictimes.indiatimes.com/news/international/business/huawei-controversial-in-the-west-is-goingstrong-in-the-gulf/articleshow/81201665.cms?from $=\mathrm{mdr}$

Aggarwal, V. \& Kapoor, M. (2018). Innovation growth from knowledge transfer in international strategic alliances. Fournal of Strategic Management, 11(4), 483-496. https://doi.org/10.1108/JSMA-06-2018-0054

Alley, A. (2020, 14. september). Ireland's Eir remains committed to keeping Huawei in its $5 \mathrm{G}$ network. Data Center Dynamics. https://www.datacenterdynamics.com/en/news/irelands-eir-remains-committedkeeping-huawei-its-5g-network/

Allison, G. (2017). Destined for war: Can America and China escape Thucydides's trap? Houghton Mifflin Harcourt.

Ansorge, J. T. (2016). Identity and sort: How digital power changed world politics. Oxford University Press.

Argue, L. (2021, 14. juli). A contentious compromise: Huawei's $5 \mathrm{G}$ involvement in Mexico and American security concerns. The Dark Wire. https://thedarkwire.com/a-contentious-compromise-huaweis-5ginvolvement-in-mexico-and-american-security-concerns/

Bienkov, A. (2020, 24. februar). Trump accused Boris Johnson of 'betrayal' after slamming the phone down on him in a moment of 'apoplectic' fury. Business Insider. https://www.businessinsider.com/trump-aloneworld-stage-boris-johnson-betrayal-huawei-uk-merkel-2020-2? $\mathrm{r}=\mathrm{US}$ andIR=T

Brands, H. (2016). Making the unipolar moment: U.S. foreign policy and the rise of the post-Cold War order. Cornell University Press.

Breakenridge, R. (2021, 4. oktober). It just got a lot easier for Ottawa to say 'no' to Huawei. Global News. https://globalnews.ca/news/8235217/canada-huawei-5g-decision-2/

Brooks, S. G. \& Wohlforth, W. C. (2008). World out of balance: International relations and the challenge of American primacy. Princeton University Press.

Brooks, S. G. \& Wohlforth, W. C. (2005). Hard times for soft balancing. International Security, 30(1), $72-108$.

Brooks, S. G. \& Wohlforth, W. C. (2016). The once and future superpower: Why China won't overtake the United States. Foreign Affairs, 95(3), 91-104.

Bueno de Mesquita, B. \& Singer, J. D. (1973). Alliance, capabilities, and war: A review and synthesis. Political Science Annual, 237-280.

Burgess, P. \& Moore, D. (1972). Inter-nation alliances: An inventory and appraisal of propositions. Political Science Annual, 3.

Carney, C. P. (1989). International patron-client relationships: A conceptual framework. Studies in Comparative International Development, 24(2), 42-55.

Christensen, T. J. (2015). The China challenge: Shaping the choices of a rising pozver. W. W. Norton \& Company. 


\section{Øystein S. Christie}

Chrysoloras, N. \& Bravo, R. (2019). Huawei deals for tech will have consequences, U.S. warns EU. Bloomberg. https:/www.bloomberg.com/news/articles/2019-02-07/huawei-deals-for-tech-will-have-consequences-us-warns-eu

Collins, K. (2019, 7. februar). US takes showdown with Huawei on the road. First stop: Europe. CNET. https:/www.cnet.com/news/the-us-takes-its-showdown-with-huawei-on-the-road-first-stop-europe/

Correlates of War Project. (2021). National material capabilities, v6.0. https://correlatesofwar.org/data-sets/ national-material-capabilities

Dreher, A., Nunnenkamp, P. \& Thiele, R. (2008). Does US aid buy UN General Assembly votes? A disaggregated analysis. Public Choice, 136(1), 139-164.

Economic Times. (2020, 15. mai). China uses trade as weapon to silence virus criticism. https://economictimes. indiatimes.com/news/international/world-news/china-uses-trade-as-weapon-to-silence-virus-criticism/ articleshow $/ 75757845 . \mathrm{cms}$

Ellyatt, H. (2019, 27. september). Are Russia and China the best of friends now? It's complicated, analysts say. CNBC. https://www.cnbc.com/2019/09/27/russia-and-chinas-relationship--how-deep-does-it-go.html

Etzioni, A. (2017). Avoiding war with China: Two nations, one world. University of Virginia Press.

Fengming, Q. (2005). 'Hou huashengdun gongshi' yu zhongguo moshi ['Post-Washington Consensus and the China Model]. Taipingyang xuebao [Pacific fournal] 6, 40-45.

Friedberg, A. L. (2011). A contest for supremacy. W. W. Norton \& Company.

Friedberg, A. L. (2018). Competing with China. Survival, global politics and strategy. Survival, 60(3), 7-64.

Friedman, U. (2020, 17. februar). America is alone in its cold war with China. The Atlantic. https://www. theatlantic.com/politics/archive/2020/02/us-china-allies-competition/606637/

Gates, R. M. (2020). The overmilitarization of American foreign policy. Foreign Affairs, July/August. https:// www.foreignaffairs.com/articles/united-states/2020-06-02/robert-gates-overmilitarization-americanforeign-policy.

Ghosh, R. (2013, 23. oktober). Economy is the most powerful weapon for China, not its missiles: Joel Zhengyi Shon. The Times of India. https://timesofindia.indiatimes.com/interviews/economy-is-the-most-powerfulweapon-for-china-not-its-missiles-joel-zhengyi-shon/articleshow/24555442.cms

Gilpin, R. (1981). War and change in world politics. Cambridge University Press.

Global Fire Power. (2021a). 2021 Military strength ranking. https://www.globalfirepower.com/countries-listing.asp

Global Fire Power. (2021b). Available military manpower. https://www.globalfirepower.com/available-militarymanpower.php

Global Times. (2021, 7. oktober). Hungary to build Europe's first smart railway port together with Huawei. https:/www.globaltimes.cn/page/202110/1235745.shtml.

Gramer, R. (2020, 27. oktober). Trump turning more countries in Europe against Huawei. Foreign Policy. https:// foreignpolicy.com/2020/10/27/trump-europe-huawei-china-us-competition-geopolitics-5g-slovakia/

Grotto, A. (2019). The Huawei problem: A risk assessment. Global Asia, 14(3), 13-15.

Hamilton, D. S. (2014). The American way of partnership (Working paper 6). European Strategic Partnerships Observatory. http://www.egmontinstitute.be/content/uploads/2014/06/ESPO_WP6.pdf?type=pdf

Hart, A. F. \& Jones, B. D. (2010). How do rising powers rise? Survival, 52(6), 63-88.

Hirschman, A. O. (1945 [1980]). National power and the structure of foreign trade. University of California Press.

Holsti, O., Hopmann, T. \& Sullivan, J. D. (1973). Unity and disintegration in international alliances. John Wiley.

Huntington, S. P. (1999). The lonely superpower. Foreign Affairs, March/April. https://www.foreignaffairs.com/ articles/united-states/1999-03-01/lonely-superpower

Jacques, M. (2009). When China rules the world: The rise of the middle kingdom and the end of the western world. Penguin Books.

Jibiki, K. \& Kawakami, T. (2020, 2. desember). Huawei’s 5G deal with Indonesia spearheads Southeast Asia push. Nikkei Asia. https://asia.nikkei.com/Spotlight/Huawei-crackdown/Huawei-s-5G-deal-with-Indonesiaspearheads-Southeast-Asia-push

Johnston, A. I. (1995). Cultural realism: Strategic culture and grand strategy in Chinese history. Princeton University Press.

Kang, D. (2007). China rising: Peace, power, and order in East Asia. Columbia University Press.

Kang, D. (2010). East Asia before the west: Five centuries of trade and tribute. Columbia University Press.

Keane, S. (2020, 11. september). Huawei ban timeline: Chinese company's Harmony OS may hit phones next year. CNET. https://www.cnet.com/news/huawei-ban-full-timeline-us-restrictions-china-trump-androidgoogle-ban-harmony-os/

Kennedy, P. (1987). The rise and fall of the great powers. Random House. 
Kennedy, S. (2010). The myth of the Beijing consensus. Fournal of Contemporary China, 19(65), 461-477.

Krauthammer, C. (1990). The unipolar moment. Foreign Affairs, 70(1), 23-33.

Lake, D. A. (2013). Legitimating power: The domestic politics of U.S. international hierarchy. International Security, 38(2), 74-111.

Lande, C. C. (1983). Political clientelism in political studies, retrospect and prospects. International Political Science Review, 4(4), 435-454.

Lanlan, H. \& Li, Q. (2020, 28. september). Lessons from Toshiba, Alstom: How U.S. suppresses foreign rival companies to maintain tech hegemony. Global Times. https:/www.globaltimes.cn/content/1202395.shtml

Layne, C. (1993). The unipolar illusion: Why new powers will arise. International Security, 17(4), 5-51.

Layne, C. (2006). The unipolar illusion revisited: The coming end of the United States' unipolar moment. International Security, 31(2), 7-41.

Layne, C. (2018). The US-Chinese power shift and the end of the Pax Americana. International Affairs, 94(1), $89-111$.

Leeds, B. A. \& Savun, B. (2007). Terminating alliances: Why do states abrogate agreements? Fournal of Politics, 69(4), 1118-1132.

Lemarchand, R. \& Legg, K. (1972). Political clientelism and development: A preliminary analysis. Comparative Politics, 4(2), 149-178.

Lennighan, M. (2021, 2. juli). Ericsson bags Malaysia's only national 5G network deal ahead of Huawei. Telecoms. https://telecoms.com/510414/ericsson-bags-malaysias-only-national-5g-network-deal-ahead-ofhuawei/

Levy, J. S. \& Thompson, W. R. (2010). Balancing on land and sea. International Security, 35(1), 7-43.

Lieber, K. A. \& Alexander, G. (2005). Waiting for balancing: Why the world is not pushing back. International Security, 30(1), 109-139.

Lindsay, J. R., Cheung, T. M. \& Reveron, D. S. (Red.). (2015). China and cybersecurity: Espionage, strategy, and politics in the digital domain. Oxford University Press.

Liska, G. (1962). Nations in alliance: The limits of interdependence. Johns Hopkins University Press.

Liska, G. (1978). Career of empire: America and imperial expansion over land and sea. John Hopkins University Press.

Lysne, O. (2018). The Huawei and Snowden questions: Can electronic equipment from untrusted vendors be verified? Can an untrusted vendor build trust into electronic equipment? Springer. https://doi.org/10.1007/978-3-31974950-1

Mahbubani, K. (2020). Has China won? The Chinese challenge to American primacy. Public Affairs.

Marek, J. \& Dutta, A. (2019, 3. oktober). A concise guide to Huawei's cybersecurity risks and the global risks. The National Bureau of Asian Research. https://www.nbr.org/publication/a-concise-guide-to-huaweiscybersecurity-risks-and-the-global-responses/

Martina, M. (2020, 28. mai). Top campaign advisor says Biden would sanction China over Hong Kong. Reuters. https://www.reuters.com/article/us-usa-election-biden-hongkong-idUSKBN23403E

Mason, J. \& Martina, M. (2021, 9. august). U.S. warned Brazil that Huawei would leave it high and dry' on 5G. Reuters. https://www.reuters.com/technology/us-warned-brazil-about-chinas-huawei-5g-networkwhite-house-official-2021-08-09/

McGregor, G. (2020, 10. januar). As U.S.-Iran tensions flare, China emerges as Tehran's last-ditch lifeline. Fortune. https://fortune.com/2020/01/10/us-iran-sanctions-china/

Mearsheimer, J. J. (2001). The tragedy of great power politics. Norton.

Mearsheimer, J. J. (2006). China's unpeaceful rise. Current History, 105(690), 160-162.

Mearsheimer, J. J. (2014). Can China rise peacefully? National Interest, 25(1), 1-40.

Onishi, T. (2020, 25. januar). Vietnam carrier develops native 5G tech to lock out Huawei. Nikkei Asian Review. https://asia.nikkei.com/Business/Telecommunication/Vietnam-carrier-develops-native-5G-tech-to-lockout-Huawei

Qingqing, C. \& Yeping, Y. (2020, 24. august). Russia is firm in 5G cooperation with Huawei: Experts. Global Times. https://www.globaltimes.cn/content/1198712.shtml

Ripsman, N. M., Taliaferro, J. W. \& Lobell, S. E. (2016). Neoclassical realist theory of international politics. Oxford University Press.

Rogers, M. \& Ruppersberger, D. (2012, 8. oktober). Investigative report on the U.S. national security issues posed by Chinese telecommunications companies Huawei and ZTE. U.S. House of Representatives, Permanent Select Committee on Intelligence. https:/stacks.stanford.edu/file/druid:rm226yb7473/Huawei-ZTE\%20 Investigative \%20Report $\% 20$ (FINAL).pdf 


\section{Øystein S. Christie}

Rothstein, R. L. (1968). Alliances and small powers. Columbia University Press.

Saddiq, S. (2019, 7. juni). Mahathir is not bowing to China on Huawei. He's standing up to US bully: Malaysian minister Syed Saddiq. South China Morning Post. https://www.scmp.com/week-asia/opinion/ article/3013585/mahathir-not-bowing-china-huawei-hes-standing-us-bully-malaysian

Sandle, P. \& Faulconbridge, G. (2020, 14. juli). UK to purge Huawei from 5G by end of 2027, siding with Trump over China. Reuters. https://www.reuters.com/article/us-britain-huawei-idUSKCN24E30P

Schelling, T. C. (1980). The strategy of conflict. Harvard University Press. (Opprinnelig utgitt 1960)

Schirm, S. A. (2010). Leaders in need of followers: Emerging powers in global governance. European fournal of International Relations, 16(2), 197-221.

Schweller, R. L. (1994). Bandwagoning for profit: Bringing the revisionist state back in. International Security, 19(1), 72-107.

Shoemaker, C. C., \& Spanier, J. W. (1984). Patron-client state relationships. Praeger.

Singer, D. J. (1988). Reconstructing the correlates of war dataset on material capabilities of states, 1816-1985. International Interactions, 14(2), 115-132.

SIPRI. (2021). SIPRI arms transfers database. Stockholm International Peace Research Institute. https://www. sipri.org/databases/armstransfers

Slezak, M. \& Bogle, A. (2018, 23. august). Huawei banned from 5G mobile infrastructure rollout in Australia. $A B C$ News. https:/www.abc.net.au/news/2018-08-23/huawei-banned-from-providing-5g-mobile-technologyaustralia/10155438

Snyder, G. (1984). The security dilemma in alliance politics. World Politics, 36(4), 461-495.

Solheim, E. (2020, 8. august). Trump vil skape kald krig med Kina. Dagens Naringsliv. https://www.dn.no/ globalt/donald-trump/kina/kald-krig/kronikk-trump-vil-skape-kald-krig-med-kina/2-1-853844

Statistics Times. (2021, 3. juni). Projected GDP ranking. https://statisticstimes.com/economy/projected-worldgdp-ranking.php

Strüver, G. (2014). 'Bereft of friends'? China's rise and search for friends in South America. Chinese fournal of International Politics, 7(1), 117-153.

Strüver, G. (2016). What friends are made of: Bilateral linkages and domestic drivers of foreign policy alignment with China. Foreign Policy Analysis, 12(2), 170-191.

Sullivan, P. L., Tessman, B. F. \& Li, X. (2011). US military aid and recipient state cooperation. Foreign Policy Analysis, 7(3), 275-294.

Tao, L. (2018, 10. desember). Japan latest country to exclude Huawei, ZTE from 5G rollout over security concerns. South China Morning Post. https:/www.scmp.com/tech/tech-leaders-and-founders/ article/,2177194/japan-decides-exclude-huawei-zte-government

The National Herald. (2020, 5. oktober). US wooing Greece away from China, Huawei $5 G$ wireless broadband. https:/www.thenationalherald.com/greece_economy/arthro/us_wooing_greece_away_from_china_ huawei_5g_wireless_broadband-956726/

Thompson, S. W. (1977). The communist international system. Orbis, 20(4), 3-21.

US Defense Manpower Data Center. (2021). DoD personnel, workforce reports $\&$ publications, June 2021. https:// dwp.dmdc.osd.mil/dwp/app/dod-data-reports/workforce-reports

US Department of State. (2021). Major non-NATO ally status. https:/www.state.gov/major-non-nato-allystatus/

Wadhams, N. \& Westall, S. (2021, 11. juni). Biden prods UAE to dump Huawei, sowing doubts on key F-35 sale. Bloomberg. https://www.bloomberg.com/news/articles/2021-06-11/biden-prods-uae-to-dumphuawei-sowing-doubts-on-key-f-35-sale

Waldemarsson, C. \& Löwenberg, W. S. (2020). No way or the Huawei? A grounded theory approach to the 5G debate in the EU [Masteroppgave]. Copenhagen Business School.

Wallace, C. B. (1992, 2. september). Nonaligned nations question new world order. Los Angeles Times.

Walt, S. M. (1987). The origins of alliance. Cornell University Press.

Walt, S. M. (2020, 30. juni). Everyone misunderstands the reason for the U.S.-China cold war. Foreign Policy. https:/foreignpolicy.com/2020/06/30/china-united-states-new-cold-war-foreign-policy/

Waltz, K. N. (1979). Theory of international politics. McGraw Hill.

Wang, D. (2020). Reigning the future: AI, 5G, Huawei, and the next 30 years of US-China rivalry. New Degree Press.

Ward, M. D. (1982). Research gaps in alliance dynamics. Graduate School of International Studies, University of Denver. 
Way, L. A. \& Levitsky, S. (2007). Linkage, leverage, and the post-communist divide. East European Politics and Societies, 21(1), 48-66.

Williamson, J. (2008). A short history of the Washington Consensus. I N. Serra, \& J. E. Stiglitz (Red.), The Washington consensus reconsidered: Towards the new global governance. Oxford University Press.

Wong, Q. \& Hautala, L. (2020, 5. august). Trump targets TikTok: Everything you need to know. CNET. https:// www.cnet.com/news/trump-targets-tiktok-everything-you-need-to-know/

World Bank. (2021). World integrated trade solution. https:/wits.worldbank.org/CountryProfile/en/Country/ JPN/Year/2018/TradeFlow/EXPIMP

Zengerle, P. (2021, 29. april). Biden talks tough on China in first speech to Congress. Reuters. https://www. reuters.com/world/us/biden-talks-tough-china-first-speech-congress-2021-04-29/

Zhou, M. (2019, 22. februar). Pompeo: Countries that use Huawei tech pose a risk to the US. CNET. https:// www.cnet.com/news/pompeo-countries-that-use-huawei-tech-pose-a-risk-to-the-us/

\section{Abstract in English \\ The US way or the Huawei: An analysis of how small and medium states stand on the Chinese giant's role in ${ }_{5} \mathrm{G}$}

This article examines the technological and strategic rivalry between the US and China on the implementation of $5 \mathrm{G}$ networks, asking what influences how other states position themselves between the two superpowers. By building on three branches of political realism - balance-of-threat theory's notion that perception of threat drives states' alliance choices, patron-client theory's belief that the US can expect its client states to adhere to American foreign policy, and the theory that trade relations can be used as power tools - I derive a set of hypotheses and potentially relevant explanatory variables. As dependent variable, I measure 70 states' stances on China's controversial telecom giant Huawei's role in 5G. Bivariate analysis reveals three primary patterns: (1) States who are dwarfed by China's power, as well as states in China's immediate geographic region, appear to be more acceptive of Huawei's 5G. (2) States who see the US as their patron and who rely on Washington's security guarantee appear to be much more rejective of the company's $5 \mathrm{G}$. (3) Trade relations to both the US and China appear to have little or no effect on states' stances. Of the three branches of realism, it is the patron-client theory that offers the most weight in explaining states' stances on Huawei's 5G.

Keywords: alliances • balancing • bandwagoning • US-China rivalry • political realism 